\title{
DEMOKRACJA BEZPOŚREDNIA W MYŚLI POLITYCZNEJ WSPÓŁCZESNYCH POLSKICH PARTII POLITYCZNYCH
}

\begin{abstract}
Przedmiotem analizy są dokumenty współczesnych partii politycznych w kontekście demokracji bezpośredniej. Demokracja bezpośrednia daje obywatelowi prawo do decydowania o najważniejszych sprawach państwowych. W Polsce instrumentami demokracji bezpośredniej są referenda i inicjatywy ludowe. Referenda są prawnie ustanowione w Konstytucji. W Polsce obywatele mogą podjąć inicjatywę referendalną przez zebranie 500 tys. podpisów.

$\mathrm{Z}$ jednej strony w dokumentach partii można znaleźć wiele informacji zachęcających obywateli do budowy społeczeństwa obywatelskiego. Politycy zachęcają do uczestnictwa w procesie podejmowania decyzji. Z drugiej zaś politycy nie wyrażają zgody na przeprowadzenie referendum. Mają lekceważący stosunek dla inicjatyw i żądań obywateli, demonstrując raczej autorytarne narzucanie własnych preferencji. W artykule autorka przedstawia dwa przykłady: decyzję rządu o objęciu obowiązkiem szkolnym dzieci sześcioletnich oraz zrównanie wieku emerytalnego dla kobiet i mężczyzn. W obu wypadkach obywatele zebrali wymaganą liczbę podpisów, ale politycy nie zgodzili się na przeprowadzenie powszechnego głosowania. Decydentom trudno sobie wyobrazić, że obywatele są zmotywowani i zdolni do uczestnictwa w procesie podejmowania decyzji. Jest to cecha charakterystyczna władzy. Powód jest prosty - politycy nie chcą się dzielić władzą $\mathrm{z}$ obywatelami.
\end{abstract}

Słowa kluczowe: demokracja bezpośrednia, partie polityczne, referendum.

W literaturze prawniczej i politologicznej termin „demokracja bezpośrednia” ma wiele definicji. Wspólną cechą większości z nich jest osobisty udział członków zbiorowego podmiotu suwerenności (obywateli państwa, narodu, ludu) w wypełnianiu różnych funkcji publicznych. Istotą jej jest to, że osoby uprawnione mogą bezpośrednio decydować, za pomocą głosowania, o różnych sprawach dotyczących danego państwa czy społeczeństwa $^{2}$. Do form demokracji bezpośredniej władze państwa bądź jego obywatele odwołują się w wypadku spraw szczególnie ważnych dla bytu państwowego określonego terytorium czy rzeczy istotnych dla danego społeczeństwa ${ }^{3}$. Demokracja bezpośrednia

${ }^{1}$ Dr hab. Małgorzata Podolak, Wydział Politologii UMCS, Lublin, e-mail: podolakm@op.pl ${ }^{2} \mathrm{~S}$. Grabowska, Instytucja ogólnokrajowej inicjatywy ludowej $w$ wybranych państwach europejskich, Rzeszów 2005, s. 18. Zob. S. Mrozowska, Demokracja uczestniczaca perspektywy europejskiej, [w:] Stan i perspektywy demokracji bezpośredniej we współczesnym świecie, red. M. Marczewsk-Rytko, Lublin 2011, s. 55-57.

${ }^{3} \mathrm{~S}$. Grabowska, Równość szans $w$ dostępie do form demokracji bezpośredniej $w$ wybranych państwach europejskich, [w:] Zasada równości w prawie, red. H. Zięba-Załucka, M. Kijowski, Rzeszów 2004, s. 116. 
pozwala na ciągły udział społeczeństwa w sprawowaniu władzy, podczas gdy demokracja pośrednia sprowadza się z reguły do systemu kontroli i ograniczenia władzy.

Opierając się na tradycji, głównie greckiej, bardzo długo uważano, że rządy demokratyczne mogą występować wyłącznie w formie bezpośredniej. W XVIII w. poszczególni autorzy zaczęli dostrzegać, że dzięki połączeniu demokratycznej zasady rządów ludu z niedemokratyczną koncepcją systemu przedstawicielskiego, demokracja może przybrać zupełnie nowy kształt i wymiar. Termin „demokracja bezpośrednia” nie ma długiej historii, ponieważ rozróżnienie terminologiczne na demokrację bezpośrednią i pośrednią datuje się na przełom XVII i XIX w., kiedy rozkwitła idea rządów ludu. Nie można było jej rozumieć, tak jak kiedyś, jako wyłącznie formę rządów bezpośrednich ${ }^{4}$.

Demokracja bezpośrednia opiera się na funkcjonowaniu instytucji bezpośredniego udziału obywateli w tworzeniu ustawodawstwa ludowego (referendum - szczególnie jako instytucja demokracji lokalnej i realnej, zgromadzenie ludowe, inicjatywa ludowa). Istotą demokracji bezpośredniej jest istnienie zbiorowej woli ludzkiej, która jest bezpośrednio związana z ludem. Naczelną jednak regułą organizacyjną demokracji przedstawicielskiej jest zasada uszanowania rzeczywistej woli większości. W nowoczesnym pluralistycznym społeczeństwie jednomyślność społeczna należy do największych rzadkości. Podział między demokracją bezpośrednią a pośrednią nie może przebiegać na płaszczyźnie realizacji ustawodawstwa, w dziedzinie administracji (wykonawstwo woli ustawodawcy) czy wymiaru sprawiedliwości. W tych sferach zagadnień problem reprezentacji nie istnieje, gdyż realizacja funkcji państwowych niejako naturalnie spoczywać musi w gestii specjalnych funkcjonariuszy, bezpośrednie działanie obywateli zaś jest wykluczone ${ }^{5}$. Idee demokracji bezpośredniej, czyli procedury umożliwiające obywatelom podejmowanie decyzji państwowych, uważa się za najpełniejszą formę demokracji. Wynika to $\mathrm{z}$ przekonania, że naród bezpośrednio decyduje o swoim losie. W Europie głęboko zakorzeniona tradycja i ukształtowane procedury stosowania tej formy demokracji występują w Szwajcarii. Oprócz tego kraju również inne państwa Europy, takie jak: Francja, Dania, Irlandia, Włochy, Liechtenstein, stosują zasady demokracji bezpośredniej6.

Poglądy na instytucję demokracji bezpośredniej ulegały zmianie w okresie transformacji ustrojowych o demokratycznym charakterze. Odwoływano się do nich, wskazując na ich różnorodne zalety i pozytywne efekty, potwierdzone praktyką niektórych krajów demokratycznych. Zauważono w nich instrument edukacji i aktywizacji politycznej społeczeństwa, bez których nie może się ukształtować społeczeństwo obywatelskie. Traktuje się zwłaszcza referendum jako najczystszą formę korelacji poglądów społeczeństwa z decyzjami jego reprezentantów ${ }^{7}$.

System najbliższy demokracji bezpośredniej występuje obecnie w Szwajcarii praktycznie każda ustawa federalna i lokalna może zostać poddana pod referendum;

${ }^{4}$ M. Rachwał, Demokracja bezpośrednia $w$ procesie ksztattowania się społeczeństwa obywatelskiego, Warszawa 2010, s. 54.

${ }^{5}$ B. Jastrzębski, O demokracji bezpośredniej, „Zeszyty Naukowe Wyższej Szkoły Pedagogicznej w Olsztynie. Nauki Prawne” 10/1 (1989), s. 40.

${ }^{6} \mathrm{M}$. Musiał-Karg, Referenda w państwach europejskich - teoria , praktyka, perspektywy, Toruń 2008, s. 49.

${ }^{7}$ M. Pietrzak, Demokracja reprezentacyjna i bezpośrednia w Konstytucji Rzeczypospolitej Polskiej, [w:] Referendum konstytucyjne w Polsce, red. M.T. Staszewski, Warszawa 1997, s. 24. 
według szacunków prowadzi się tam więcej referendów niż we wszystkich pozostałych państwach świata łącznie. Generalną tendencją jest, że na poziomie samorządowym występuje system bliższy demokracji bezpośredniej niż na poziomie wyższym ${ }^{8}$. Wynika to $\mathrm{w}$ znacznym stopniu $\mathrm{z}$ uwarunkowań historycznych, co $\mathrm{w}$ praktyce umożliwiają warunki geograficzne tego państwa. W innych systemach ustrojowych demokracja bezpośrednia znajduje zastosowanie głównie na szczeblu lokalnym (np. Anglia, Stany Zjednoczone $)^{9}$.

Przedmiotem artykułu jest analiza dokumentów głównych partii politycznych występujących współcześnie w parlamencie polskim - Platformy Obywatelskiej, Prawa i Sprawiedliwości, Polskiego Stronnictwa Ludowego, Sojuszu Lewicy Demokratycznej oraz Twojego Ruchu - i próba odpowiedzi na dwa pytania. 1. Czy w dokumentach partii politycznych można znaleźć zagadnienia związane z demokracją bezpośrednią? 2. Jak wygląda stanowisko partii politycznych w przełożeniu na praktykę polityczną?

Po analizie dokumentów można stwierdzić następujące fakty. Po pierwsze w dokumentach wszystkich analizowanych partii politycznych znajduje się wiele informacji związanych $\mathrm{z}$ demokracją bezpośrednią. Mowa jest o budowie społeczeństwa obywatelskiego, wzbudzaniu aktywności obywateli, inicjatywach obywatelskich ${ }^{10}$.

W exposé premiera Donalda Tuska wygłoszonym 23 listopada 2007 r. mowa jest o tym, że: „[...] podstawą każdego demokratycznego państwa jest społeczeństwo obywatelskie. Nie da się go odgórnie zadekretować ani zbudować poprzez działania administracyjne. Może jednak trzeba je wspomagać poprzez tworzenie ułatwień i przyjaznej przestrzeni dla organizacji pozarządowych. W ostatnich dwóch latach słyszeliśmy często z ust przedstawicieli rządu centralnego słowa świadczące o braku zaufania do tych instytucji życia publicznego, które nazywamy sektorem pozarządowym. Chciałbym, abyśmy jak najszybciej uruchomili prace nad strategią rozwoju społeczeństwa obywatelskiego, która objęłaby najbliższe 15-20 lat"" . Wygłaszając kolejne exposé 18 listopada 2011 r. premier Tusk nie nawiązywał już do żadnych form demokracji bezpośredniej, podobnie premier Ewa Kopacz ${ }^{12}$. W programie wyborczym PO Następny krok. Razem. Program wyborczy 2011 partia podniosła znaczenie konsultacji

${ }^{8}$ Zob. M. Marczewska-Rytko, Szwajcarski model demokracji bezpośredniej, [w:] Stan i perspektywy demokracji bezpośredniej we wspótczesnym świecie, Lublin 2011, s. 323-345.

${ }^{9}$ J. Czajowski, Przedstawicielska forma rzqdów i demokracja bezpośrednia, [w:] Szkice o zasadach i instytucjach ustrojowych II i III Rzeczypospolitej, red. J. Czajowski, M. Grzybowski, Kraków 2002, s. 70.

${ }^{10}$ Zob. M. Podolak, Demokratyzacja spoteczeństwa polskiego w okresie transformacji, [w:] Aksjologiczny i pragmatyczny wymiar wspótczesnej polityki, red. D. Walczak-Duraj, Łódź 2011, s. 83-97.

11 „Sprawozdanie Stenograficzne z 2 posiedzenia Sejmu RP w dniu 23 listopada 2007 r.”,

Przedstawienie przez prezesa Rady Ministrów Donalda Tuska programu dziatania Rady Ministrów z wnioskiem o udzielenie jej wotum zaufania 23.11.2007 r., http://orka2.sejm.gov.pl/StenoInter6.nsf. 20.09.2014

${ }^{12}$ Zob. „Sprawozdanie Stenograficzne z 1 posiedzenia Sejmu RP w dniu 18 listopada 2011 r.”, Przedstawienie przez prezesa Rady Ministrów Donalda Tuska programu dziatania Rady Ministrów z wnioskiem o udzielenie jej wotum zaufania 18.11.2011, http://orka2.sejm.gov.p1/StenoInter7.nsf; 20.09.2014, ,Sprawozdanie Stenograficzne z 76 posiedzenia Sejmu RP w dniu 1 października 2014 r.”, Przedstawienie przez Prezesa Rady Ministrów programu dziatania Rady Ministrów z wnioskiem o udzielenie jej wotum zaufania, http://orka2.sejm.gov.pl/StenoInter7.nsf. 20.09.2014 
społecznych: „Zgodnie z filozofią kreatywności i współpracy zaprosimy wszystkich do interaktywnego opiniowania projektów i pomysłów rządu od najwcześniejszego etapu. Wykorzystamy Internet i portale społecznościowe do aktywnej moderacji dyskusji nad projektami rządowymi i poselskimi. Wprowadzimy obowiązek analizy propozycji płynących od obywateli przez rządowe centrum analityczne"13.

O budowaniu społeczeństwa obywatelskiego i jego znaczeniu dla państwa mowa jest w programie wyborczym Sojuszu Lewicy Demokratycznej Jutro bez obaw Program dla Polski, 2011. Według autorów programu „społeczeństwo obywatelskie to społeczeństwo aktywnie uczestniczące we wszystkich aspektach życia społecznego szanujące swoje państwo z jego porządkiem prawnym i historią" ${ }^{14}$. W rozdziale I Państwo p. 2.1. „Udział obywateli w organizacjach społecznych we władzy samorządowej”: „Warunkiem partycypacji społecznej i pobudzania rozwoju społecznego jest wnikliwe badanie potrzeb mieszkańców i ich oczekiwań wobec samorządów. Partycypacja społeczna jest nieodłącznie związana $\mathrm{z}$ komunikacją społeczną $\mathrm{i}$ przejrzystością informacyjną, realizowanymi poprzez organizowanie cyklicznych spotkań, konsultacji, zgromadzeń obywateli czy wysłuchań publicznych poświęconych najważniejszym problemom społeczności"15.

Podobnie twórcy programu Polskiego Stronnictwa Ludowego opowiadają się za aktywnym społeczeństwem. W dokumencie programowym X Kongresu PSL Polskie Stronnictwo Ludowe wobec problemów i wyzwań dla Polski w rozdziale 1 Strategiczne wyzwania napisano: „1. Aktywne społeczeństwo warunkiem rozwoju państwa i obywateli. Polskie Stronnictwo Ludowe uznaje, że tylko aktywne społeczeństwo - aktywni w życiu publicznym obywatele, świadomi swoich celów, praw i obowiązków - jest w stanie podźwignąć Polskę do rangi przodujących narodów. PSL, przez swój udział w rożnych sferach życia publicznego, będzie stwarzać warunki, aby ambitni i samodzielni obywatele mogli brać «sprawy w swoje ręce»"16.

W Programie Twojego Ruchu Plan Zmian 2014-2019 akcentuje się udział obywateli w bieżącym funkcjonowaniu państwa. Mają temu służyć „lokalne i ogólnokrajowe referenda, jak również konsultacje społeczne, zarówno na poziomie krajowym (włączenie organizacji pozarządowych i innych instytucji społeczeństwa obywatelskiego w proces legislacyjny), jak i lokalnym (m.in. budżety partycypacyjne). Autorzy programu zwracają uwagę na rozwój technologii informatycznych, który ma służyć obywatelom w procesie podejmowania decyzji" 17 .

W programie Prawa i Sprawiedliwości znajdują się zapowiedzi reformy sektora obywatelskiego: „W celu zaktywizowania społeczeństwa polskiego wokół realizacji dobra publicznego, kształtowania wspólnotowych motywacji i patriotycznych postaw obywateli, i tym samym stworzenia warunków dla poprawy sprawności rządzenia w Polsce, konieczna jest systemowa reforma sektora obywatelskiego. Współczesne demokracje nie mogą i nie potrafią sprawnie funkcjonować bez rozwiniętych i nowoczesnych struktur

\footnotetext{
${ }^{13}$ Następny krok. Razem. Program wyborczy 2011, http://www.platforma.org/media/dokumenty , 05.09.2014

${ }^{14}$ Jutro bez obaw Program dla Polski [Program wyborczy Sojuszu Lewicy Demokratycznej], [b.m.] 2011, s. 17. http://www.sld.org.pl/strony/39-jutro_bez_obaw_program_sld.html, 10.09.2014 ${ }^{15}$ Ibidem, s. 36.

${ }^{16}$ Dokument Programowy X zjazdu PSL, http://www.psl.org.pl/upload/pdf/dokumenty, 29.08.2014

${ }^{17}$ Program Twojego Ruchu Plan Zmian 2014-2019, http://twojruch.eu/wp-content, 15.09.2014
} 
obywatelskich. Instytucje obywatelskie pełnią bowiem w demokracji ważne i unikalne funkcje decydujące o jej jakości i sprawności państwa, takie jak: artykulacja i rzecznictwo interesów oraz obrona wartości różnorakich grup społecznych; kontrola władzy na różnych jej szczeblach i w rozmaitych postaciach (w tym także formy uzasadnionego protestu pracowników, konsumentów i obywateli oraz nieposłuszeństwo obywatelskie); uczestnictwo w procesach przygotowywania, konsultowania, podejmowania i realizacji decyzji politycznych; formułowanie alternatyw rozwojowych; samodzielne zagospodarowywanie rozmaitych sfer życia społecznego"18.

W projekcie Konstytucji RP zaproponowanej przez PiS w 2010 r. przedstawiono propozycję rozbudowania obecnych form demokracji bezpośredniej o formy nieznane $\mathrm{w}$ Polsce, ale znane i stosowane $\mathrm{z}$ powodzeniem na świecie $\mathrm{i}$ w Europie ${ }^{19}$. Polska konstytucja przewiduje dwie formy demokracji bezpośredniej, mianowicie: referendum i inicjatywę ludową. Art. 125 Konstytucji stanowi, że w sprawach o szczególnym znaczeniu dla państwa może być przeprowadzone referendum. Referendum to ma charakter fakultatywny - o czym świadczy użycie przez ustawodawcę zwrotu „może”. Podmioty, które mogą wystąpić z inicjatywą referendum to: 1) Sejm, uchwałą podjętą bezwzględną większością głosów w obecności co najmniej połowy ustawowej liczby posłów, lub 2) Prezydent, za zgodą Senatu wyrażoną bezwzględną większością głosów w obecności co najmniej połowy ustawowej liczby senatorów ${ }^{20}$.

W Konstytucji RP znajdują się dwa przepisy (art. 90 ust. 3 i art. 235 ust.6), które wskazują dwie grupy spraw, mogące być przedmiotem referendum ogólnokrajowego. Po pierwsze w Konstytucji uregulowane zostały kwestie dotyczące referendum w sprawie zmiany konstytucji (art. 235 ust 6). Referendum to może zostać przeprowadzone w wypadku zmiany przepisów konstytucji dotyczących zasad naczelnych, wolności, praw i obowiązków człowieka i obywatela oraz samej procedury zmiany konstytucji (rozdziały I, II i XII). W tym wypadku referendum zostaje zarządzone przez Marszałka Sejmu w terminie 60 dni od daty złożenia wniosku przez podmiot występujący z inicjatywą zmiany konstytucji (1/5 ustawowej liczby posłów, Prezydent, Senat). Wymienione podmioty mogą w terminie 45 dni od uchwalenia ustawy przez Senat żądać przeprowadzenia referendum zatwierdzającego. Zmiana konstytucji zostanie przyjęta wtedy, gdy opowie się za nią większość głosujących. Przepisy art. 235 Konstytucji nie dają wprost jasnej odpowiedzi na pytanie, czy mogą one stanowić podstawę normatywną uchwalenia w przyszłości nowej konstytucji czy też służyć mogą jedynie za podstawę częściowej nowelizacji (zmian) obecnej Konstytucji ${ }^{21}$.

\footnotetext{
${ }^{18}$ Program PiS 2014 Projekt dla Polski, file:///C:/Users/admin/Downloads/program_pis_2014.pdf, s. 144, 15.09.2014.

${ }^{19}$ Zob. szerzej: M. Podolak, Rola i znaczenie demokracji bezpośredniej we wspótczesnych państwach, [w:] Polityczne wyzwania wspótczesnych państw. Perspektywa globalna, t. 1, red. W. Gizicki, Lublin 2011, s. 126-141.

${ }^{20}$ Zob. J. Czajowski, Zasada podziału władz, [w:] Szkice o zasadach i instytucjach ustrojowych II $i$ III Rzeczypospolitej, red. J. Czajowski, M. Grzybowski, Kraków 2002, s. 87-96.

${ }^{21} \mathrm{~A}$. Szmyt, Zasady zmiany konstytucji Rzeczypospolitej Polskiej, [w:] Zasady zmiany konstytucji w państwach europejskich, red. R. Grabowski, S. Grabowska, Warszawa 2008, s. 272. Zob. W. Sokolewicz, Tezy do art. 225, [w:] Konstytucja Rzeczypospolitej Polskiej. Komentarz, t. 2, red. L. Garlicki, Warszawa 2001, s. 1-75.
} 
W konstytucji znalazł się także zapis w art. 90 ust. 3 przewidujący możliwość odwołania się do referendum jako alternatywnej do procedury parlamentarnej formy wyrażania zgody w sprawie przekazania organizacji międzynarodowej lub organowi międzynarodowemu kompetencji organów władzy państwowej w niektórych sprawach. Referendum to przeprowadza się zgodnie z przepisem art. 125 (art. 90 ust. 3). O wyborze referendum decyduje wyłącznie Sejm, podejmując stosowną uchwałę bezwzględną większością głosów, w obecności co najmniej połowy ustawowej liczby posłów (art. 90 ust. 4) ${ }^{22}$. Referendum to nie jest jedyną dopuszczalną formą wyrażenia owej zgody, ponieważ może ona zostać podjęta $\mathrm{w}$ wyniku przyjęcia $\mathrm{w}$ specjalnym trybie ustawy uchwalonej większością 2/3 głosów w Sejmie i 2/3 głosów w Senacie, w obecności co najmniej połowy ustawowej liczby posłów i senatorów (art. 90 ust. 4). Decyzje w sprawie wyboru trybu wyrażenia zgody na taką ratyfikację podejmuje Sejm uchwałą przyjętą bezwzględną większością głosów, w obecności co najmniej połowy ogólnej liczby posłów (art. 90 ust. 4). Rozstrzygnięcie Sejmu oznaczające wybór trybu referendalnego rodzi po stronie podmiotów uprawnionych przez art. 125 ust. 2 Konstytucji do zarządzenia referendum ogólnokrajowego (Sejmu i Prezydenta) obowiązek zarządzenia referendum ratyfikacyjnego. Można więc mówić o warunkowym (zależnym od uchwały Sejmu) referendum obligatoryjnym. Referendum to ma w pewnym stopniu charakter referendum wstępnego, w takim mianowicie znaczeniu, że nie zastępuje ono aktu ratyfikacji ${ }^{23}$.

We wszystkich wypadkach referendum może, lecz nie musi być zarządzone, co oznacza że są one fakultatywne. W wypadku referendum ogólnokrajowego o szczególnym znaczeniu dla państwa i referendum ogólnokrajowego w sprawie wyrażenia zgody na ratyfikację umowy międzynarodowej, żeby były one wiążące dla władzy, wymaga się, aby wzięła w nich udział więcej niż połowa uprawnionych do głosowania. Wymogu takiego nie ma w wypadku referendum ogólnokrajowego zatwierdzającego zmianę Konstytucji RP ${ }^{24}$

Obywatelska inicjatywa ustawodawcza została wprowadzona wraz $\mathrm{z}$ uchwaleniem Ustawy Zasadniczej z 1997 r., jednak dopiero z chwilą wejścia w życie ustawy o wykonywaniu inicjatywy ludowej z 23 sierpnia 1999 r. można stwierdzić, że konstytucyjnie przyznane prawo mogło zostać wykorzystane przez suwerena w III RP. W myśl polskich przepisów konstytucyjnych z inicjatywą ustawodawczą może wystąpić grupa 100 tys. obywateli (art. 118 Konstytucji) mających czynne prawo wyborcze ${ }^{25}$. W wypadku wniosku o przeprowadzenie referendum ogólnokrajowego może wystąpić do Sejmu grupa co najmniej 500 tys. obywateli (art. 63 ustawy o referendum z 2003 r.). Z punku widzenia przedmiotowego inicjatywa ludowa obejmuje ten sam zakres materii, $\mathrm{w}$ którym prawo inicjatywy ustawodawczej przysługuje innym podmiotom: Prezydentowi, rządowi, Senatowi, grupie posłów. Nie obejmuje jedynie materii zastrzeżonych do

\footnotetext{
${ }^{22}$ M. Jabłoński, Wynik referendum, a zasada dyskontynuacji prac parlamentu, „Przegląd Prawa i Administracji” 1998/41, s. 99.

${ }^{23}$ J. Kuciński, Demokracja przedstawicielska i bezpośrednia w trzeciej Rzeczypospolitej, Warszawa 2007, s. 235.

${ }^{24}$ M. Grabowska, Polska ustawa o referendum ogólnokrajowym (referenda akcesyjne), „Studia Europejskie" 2003/1, s. 104

${ }^{25}$ W. Skrzydło, Konstytucja Rzeczypospolitej Polskie. Komentarz, Kraków 2002, s 151; zob. „Ustawa z dnia 24 czerwca 1999 r. o wykonywaniu inicjatywy ustawodawczej przez obywateli”, Dziennik Ustaw", 1999, nr 62, poz. 688.
} 
wyłącznej inicjatywy ustawodawczej Rady Ministrów. W obecnym stanie prawnym w Polsce można wyróżnić dwa rodzaje inicjatywy ludowej:

- $\quad$ inicjatywę ludową w sprawie przeprowadzenia referendum regulowaną art. 125 ust. 5 i art. 170 Konstytucji RP i ustawą o referendum z 2003 r. oraz ustawą z 15 września 2000 r. o referendum lokalnym;

- $\quad$ obywatelską inicjatywę ustawodawczą regulowaną art. 118 ust. 2 Konstytucji RP i ustawą z 24 czerwca 1999 r. o wykonywaniu inicjatywy ustawodawczej przez obywateli.

Pierwsza z nich może mieć zasięg ogólnokrajowy lub lokalny i nie może dotyczyć zmiany konstytucji. Natomiast druga może mieć tylko charakter ogólnokrajowy i odnosi się do ustawodawstwa zwykłego ${ }^{26}$. W projekcie Konstytucji $\mathrm{PiS}^{27} \mathrm{w}$ art. 8 pozostawiono instytucję referendum ogólnokrajowego w sprawach o szczególnym znaczeniu dla państwa. Podmiotami, które mogą zarządzić referendum, są Prezydent za zgodą Senatu oraz Sejm bezwzględną większością głosów. Wynik referendum krajowego jest wiążący, jeżeli w głosowaniu wzięło udział co najmniej 30\% uprawnionych (obecnie połowa uprawnionych do głosowania obywateli), z zastrzeżeniem art. 175 ust. 2. Artykuł 175 dotyczy ratyfikacji umowy międzynarodowej dającej możliwość przekazania przez RP organizacji międzynarodowej lub organowi międzynarodowemu kompetencji organów władzy państwowej w niektórych sprawach. Referendum zarządza sejm. Wynik referendum w tej sprawie jest wiążący, jeżeli w głosowaniu wzięła udział co najmniej połowa uprawnionych. Pozostawiono także bez większych zmian ludową inicjatywę obywatelską.

Nowością w projekcie konstytucji jest art. 105 „szczególne przypadki inicjatywy ustawodawczej przez Prezydenta i Radę Ministrów". Prezydent może zarządzić przeprowadzenie referendum krajowego w sprawie przygotowanego przez siebie projektu ustawy przed złożeniem inicjatywy w Sejmu. Jeżeli Naród wiążąco wypowiedział się za projektem prezydenckim, Prezydent Rzeczypospolitej składa go Marszałkowi Sejmu w ciągu 7 dni od dnia ogłoszenia wyniku referendum krajowego. W takim wypadku Sejm i Senat mogą wnosić poprawki jedynie za zgodą Prezydenta Rzeczypospolitej, a Senat nie może odrzucić ustawy uchwalonej przez Sejm. Jeżeli Sejm nie uchwali ustawy w ciągu 90 dni od złożenia jej projektu, Prezydent Rzeczypospolitej może zarządzić skrócenie kadencji Sejmu w ciągu 14 dni od bezskutecznego upływu tego terminu, a jeżeli przed jego upływem Sejm odrzucił projekt ustawy - w ciągu 14 dni od dnia odrzucenia projektu. Jest to wypadek fakultatywnego skrócenia kadencji Sejmu.

Kolejną nowością jest weto ustawodawcze stosowane przez Prezydenta w świetle art. 103 projektu Konstytucji. Jeżeli ustawa ma istotne znaczenie dla finansów publicznych lub wolności i praw obywateli, Prezydent Rzeczypospolitej, jeśli nie stosuje zwykłego weta ustawodawczego, może w ciągu 30 dni od przedstawienia mu ustawy przez Marszałka Sejmu zarządzić przeprowadzenie referendum krajowego w sprawie jej podpisania (szczególne weto ustawodawcze). Prezydent Rzeczypospolitej podpisuje ustawę w ciągu 7 dni od ogłoszenia wyniku referendum, jeżeli Naród wiążąco wypowiedział się za jej podpisaniem albo jeżeli wynik referendum nie jest wiążący. Jeśli Naród wiążąco wypowiedział się przeciwko podpisaniu ustawy, postępowanie

${ }^{26} \mathrm{~S}$. Grabowska, Formy demokracji bezpośredniej w wybranych państwach europejskich, Rzeszów 2009, s. 140-141.

${ }^{27}$ Konstytucja Rzeczypospolitej Polskie, projekt Prawa i Sprawiedliwości, Warszawa 2010, file:///C:/Users/admin/Downloads/konstytucja_2010.pdf.,21.09.2014 
ustawodawcze jest zakończone. W takim wypadku Prezydent Rzeczypospolitej może w ciągu 14 dni od ogłoszenia wyniku referendum zarządzić skrócenie kadencji Sejmu. Jest to kolejny przypadek możliwości skrócenia kadencji Sejmu przez prezydenta RP. Weto to jest odpowiednikiem weta ludowego stosowanego w Szwajcarii i we Włoszech. Daje ono możliwość zakwestionowania, w określonym czasie, uchwalonego już aktu prawnego przez grupę obywateli danego państwa. Instytucja ta jest związana również z referendumweto. Ma to związek z tym, że wystąpienie $\mathrm{z}$ inicjatywą ludową kwestionującą dany akt prawny pociąga za sobą $\mathrm{z}$ reguły konieczność przeprowadzenia referendum $\mathrm{w}$ tej sprawie, która zadecyduje, czy oprotestowany akt prawny będzie nadal obowiązywał, czy tez zostanie zmieniony bądź uchylony ${ }^{28}$. Najczęściej inicjatorami przeprowadzenia weta ludowego są sami obywatele, którzy w wyniku inicjatywy ludowej składają wnioski w sprawie przeprowadzenia referendum-weta. Podjęcie inicjatywy w zakresie weta ludowego wzmacnia znacząco aktywność obywateli w sprawie ustawy, która nie zyskuje ich akceptacji. Nie bez znaczenia jest także nagłośnienie i spopularyzowanie stanowiska ludzi w danej sprawie, nawet jeśli nie będzie osiągnięty sukces ${ }^{29}$.

Po raz pierwszy zostało ono zastosowane w 1831 r. w Szwajcarii, w kantonie SaintGall $^{30}$. Używanie do określenia tej formy demokracji bezpośredniej nazwy referendumweto jest związane $\mathrm{z}$ tym, że konsekwencją zastosowania tego środka prawnego jest $\mathrm{z}$ reguły konieczność poddania zakwestionowanego aktu prawnego pod głosowanie powszechne, które może je uchylić. Generalnie nie jest to forma, w jakiej suweren regularnie ingeruje w proces sprawowania władzy państwowej ${ }^{31}$. Weto ludowe można uznać za przeciwieństwo inicjatywy ludowej, gdyż inicjatywa służy do inicjowania procesu legislacyjnego, weto zaś do zgłoszenia sprzeciwu wobec uchwalonej przez parlament ustawy ${ }^{32}$. W Polsce rolę weta odgrywa referendum lokalne w sprawie odwołania organów stanowiących samorządu terytorialnego. Brak natomiast odpowiednich regulacji kształtujących wprost instytucję weta ludowego w odniesieniu do aktów prawnych ${ }^{33}$.

Podsumowując projekt Konstytucji PiS, nasuwają się następujące wnioski:

1. formy demokracji bezpośredniej są rozbudowane w stosunku do obecnej Konstytucji;

2. nowość - weto ustawodawcze stosowane przez Prezydenta oraz szczególne przypadki inicjatywy ustawodawczej dające Prezydentowi możliwość zwrócenia się do społeczeństwa z projektem ustawy przed złożeniem jej do Sejmu;

\footnotetext{
${ }^{28}$ S. Grabowska, Formy demokracji.., s. 29.

${ }^{29}$ Zob. E. Popławska, Zasada rządów przedstawicielskich i formy demokracji bezpośredniej, [w:] Zasady podstawowe polskiej Konstytucji, red. W. Sokolewicz, Warszawa 1998, s. 140.

${ }^{30}$ J. Litawski, Bezpośrednie ustawodawstwo ludowe, Kraków 1932, s. 18.

${ }^{31} \mathrm{~B}$. Banaszak, Porównawcze prawo konstytucyjne wspótczesnych państw demokratycznych, Kraków 2000, s. 319.

${ }^{32}$ Zob. P. Uziębło, Inicjatywa ustawodawcza obywateli w Polsce na tle rozwiazań ustrojowych państw obcych, Warszawa 2006, s. 52.

${ }^{33}$ Zob. rozważania A. Degreit, Weto ludowe, http://alexdegrejt.salon24.p1/405985, weto-ludowe; Program Partii Demokracja Bezpośrednia,
} http://db.org.pl/sites/default/files/turkusowa_rewolucja.pdf, 15.06.2014. 
3. wzmocniona pozycja prezydenta wobec Sejmu - możliwość skrócenia kadencji w określonych wypadkach nieuzyskania przez naród akceptacji dla projektów ustaw uchwalonych przez parlament;

4. obniżenie progu ważności referendum ogólnokrajowego do 30\% (obecnie połowa uprawnionych do głosowania obywateli) - możliwość zwiększenia wpływu obywateli na proces podejmowania decyzji.

Jak można zauważyć w tych dokumentach politycy zachęcają obywateli do aktywnego włączania się w sprawy, które są przedmiotem debaty publicznej. Poniżej zaprezentowano dwa przykłady aktywności obywatelskiej związanej z inicjatywami referendalnym. Pojawiły się one jako głosy sprzeciwu wobec reform przeprowadzanych przez rządy POPSL.

Pierwsza sprawa dotyczy sześciolatków i ich obowiązku szkolnego. Obowiązek szkolny dla dzieci sześcioletnich został wprowadzony ustawą w 2009 r. Początkowo wszystkie sześciolatki miały pójść do pierwszej klasy od 1 września 2012 r., natomiast w latach 2009-2011 o podjęciu nauki mogli decydować rodzice. Sejm, chcąc dać samorządom dodatkowy czas na przygotowanie szkół, przesunął ten termin o dwa lata, do 1 września 2014 r. W sierpniu tego roku Sejm zdecydował, że w 2014 r. obowiązkiem szkolnym objęte zostaną tylko sześciolatki urodzone w pierwszej połowie $2008 \mathrm{r}$. Pozostałe dzieci z tego rocznika rozpoczną naukę w roku $2015^{34}$.

Rodzice sześciolatków, mając wolny, wybór rzadko i z roku na rok coraz bardziej niechętnie posyłają swoje dzieci do pierwszej klasy (2011/2012 - 19\%, 2012/2013 - 17\%, $2013 / 2014-15 \%$ ). Szkoły są likwidowane wbrew protestom lokalnych społeczności. Stowarzyszenie i Fundacja Rzecznik Praw Rodziców, które założyli Karolina i Tomasz Elbanowscy, 8 stycznia 2013 r. rozpoczęły zbiórkę podpisów pod wnioskiem o ogólnopolskie referendum edukacyjne „Ratujmy maluchy i starsze dzieci też”. Celem inicjatywy było ostateczne odwołanie przez rząd reformy obniżenia wieku szkolnego ${ }^{35}$. Zebrano 1,4 mln podpisów i w czerwcu wniosek został złożony do Sejmu.

Zaproponowano pięć pytań referendalnych:

1. Czy jesteś za zniesieniem obowiązku szkolnego sześciolatków?

2. Czy jesteś za zniesieniem obowiązku przedszkolnego pięciolatków?

3. Czy jesteś za przywróceniem w liceach ogólnokształcących pełnego kursu historii oraz innych przedmiotów?

4. Czy jesteś za stopniowym powrotem do systemu: 8 lat szkoły podstawowej plus 4 lata szkoły średniej?

5. Czy jesteś za ustawowym powstrzymaniem procesu likwidacji publicznych szkół i przedszkoli?

Inicjatorzy referendum, państwo Karolina i Tomasz Elbanowscy, odbyli wiele spotkań z politykami, próbując przekonać ich do swoich racji ${ }^{36}$. W Sejmie odbyła się debata na 52 posiedzeniu Sejmu 22-24 października 2013 r. oraz na 53 posiedzeniu Sejmu 6-8

\footnotetext{
${ }^{34}$ PiS złożyt wniosek o referendum ws. 6-latków, http://wiadomosci.wp.pl.20.07.2014

${ }^{35}$ Referendum edukacyjne „Ratujmy maluchy i starsze dzieci też”, http://www.rzecznikrodzicow.pl. 20.07.2014

${ }^{36} \mathrm{PAP}$, Elbanowski: spotkanie z premierem ws. sześciolatków było bez konkretów, http://wiadomosci.wp.pl; 20.07.2014, Ratujmy maluchy $u$ premiera 27 grudnia, http://www.rzecznikrodzicow.pl; 20.07.2014, Ratuj maluchy u Millera 24.09, http://www.rzecznikrodzicow.pl. 20.07.2014
} 
listopada 2013 r. W dyskusji wziął udział także premier Donald Tusk próbują przekonać, że obawy rodziców sześciolatków są bezzasadne i szkoły są przygotowane na przyjęcie dzieci: „W sprawie sześciolatków parlament podjął decyzję większością głosów, że sześciolatki i szkoły w Polsce są wystarczająco przygotowane, aby podjąć ten wysiłek edukacyjny, przy sprzeciwie i obawach mniejszości w parlamencie" "37. Stanowisko Klubu Parlamentarnego Prawo i Sprawiedliwość zaprezentował poseł Sławomir Kłosowski. Klub zdecydowanie popierał inicjatywę. Poseł przedstawił wyniki kontroli NIK „Przygotowanie gmin i szkół do objęcia dzieci 6-letnich obowiązkiem szkolnym” opublikowane 17 października 2013 r. W dokumencie tym stwierdzono, że 56\% szkół nie zapewniło uczniom klas pierwszych dostosowanych do wymagań mebli szkolnych, 19\% szkół nie zapewniło uczniom klas pierwszych możliwości realizacji zajęć wychowania fizycznego, $15 \%$ szkół nie dysponowało wydzielonym pomieszczeniem na świetlicę szkolną, 19\% szkół nie zapewniło uczniom klas pierwszych dostosowanych do wymagań warunków w szatni szkolnej, 35\% szkół zajęcia opiekuńczo-wychowawcze w świetlicy szkolnej organizowało w grupach przekraczających dopuszczalną liczbę 25 uczniów, 84\% szkół zaś nie zapewniło uczniom klas pierwszych możliwości pracy przy osobnym komputerze w pracowni komputerowej.

Głosowanie odbyło się 8 listopada 2013 r. - za wnioskiem opowiedziało się 222 posłów przeciw 232. Za wnioskiem była cała opozycja: PiS, Twój Ruch, SLD, SP. Natomiast PO i PSL opowiedziało się odrzuceniem wniosku, z klubowej dyscypliny wyłamało się dwóch posłów PSL: Eugeniusz Kłopotek i Andrzej Dąbrowski, którzy poparli wniosek ${ }^{38}$. Poseł Kłopotek stwierdził, że głosował zgodnie z własnym sumieniem, spodziewając się kary. Według profesora Janusza Czapińskiego, który wypowiedział się w TVN24, jest mało prawdopodobne, aby Polacy (w wypadku zorganizowania referendum) poszli do urn i oddali swój głos. Sprawę tę należy potraktować jako wstęp do dyskusji o polskiej szkole ${ }^{39}$.

Druga kwestia nagłośniona w mediach to sprawa wieku emerytalnego. Wyższy wiek emerytalny obowiązuje w Polsce od 1 stycznia 2013 r. ${ }^{40}$. Zrównany dla obu płci wiek emerytalny wynosi 67 lat dla kobiet i mężczyzn. Przed nowelizacją wiek emerytalny kobiet wynosił 60 lat, a mężczyzn 65. Wprowadzone zmiany objęły kobiety urodzone po 31 grudnia 1952 r. oraz mężczyzn urodzonych po 31 grudnia $1947 \mathrm{r}$.

Najważniejszym efektem podniesienia wieku emerytalnego $\mathrm{z}$ punktu widzenia rozwoju gospodarczego ma być powstrzymanie spadku zatrudnienia, a w konsekwencji utrzymanie wzrostu PKB oraz wpływów podatkowych od przedsiębiorstw, które nie będą

\footnotetext{
${ }^{37}$ Wypowiedzi na posiedzeniach Sejmu, Posiedzenie nr 53 w dniu 08-11-2013 (3. dzień obrad), http://www.sejm.gov.pl/Sejm7.nsf.05.09.2014

${ }^{38} \mathrm{http}$ //www.tvn24.pl/wiadomosci-z-kraju,3/przegrali-bitwe-o-referendum-ws-6-latkow-walcza-oodmrozenie-projektu-rodzice-beda-pamietac,373758.html, 22.09.2014.

${ }^{39} \mathrm{Nie}$ będzie referendum ws. 6-latków. Koalicja wygrała głosowanie, http://www.tvn24.pl/wiadomosci-z-kraju,3/nie-bedzie-referendum-ws-6-latkow-koalicja-wygralaglosowanie,369867.html, 22.09.2014

${ }^{40}$ Ustawa z dnia 11 maja 2012 r. o zmianie ustawy o emeryturach i rentach z Funduszu Ubezpieczeń Spotecznych oraz niektórych innych ustaw, Dz.U. z 2012, poz. 637.
} 
zmuszone do likwidacji miejsc pracy w nadchodzącym okresie ograniczenia podaży $\operatorname{pracy}^{41}$.

Ostatnio silnym bodźcem stał się kryzys finansowy, który uświadomił politykom i opinii publicznej, jak istotną część systemu finansowego stanowi system emerytalny. Kryzys uprzytomnił także znaczenie wydajności oraz bezpieczeństwa systemów emerytalnych dla spójności społecznej. Jednocześnie od wielu lat do podejmowania debaty i wdrażania reform zachęcają prognozy demograficzne ${ }^{42}$.

Poniżej zaprezentowano najważniejsze argumenty, które zostały przedstawione w uzasadnieniu do projektu ustawy o zmianie ustawy o emeryturach i rentach z Funduszu Ubezpieczeń Społecznych oraz niektórych innych ustaw, które uzasadniają wydłużenie i zrównanie wieku emerytalnego:

1. Polska to kraj, w którym najwcześniej przechodzi się na emeryturę. Polska jest jednym z ostatnich krajów w Unii, który nie podniósł powszechnego wieku emerytalnego przynajmniej do 65 lat dla kobiet i mężczyzn.

2. Rośnie dysproporcja między liczbą osób w wieku produkcyjnym i emerytalnym, ponieważ: Polacy żyją dłużej, spada liczba narodzin, coraz więcej Polaków dłużej się uczy.

3. Zmiany dotyczące wydłużania i zrównywania powszechnego wieku emerytalnego będą następowały stopniowo, co da czas na dostosowanie na rynku pracy, zarówno po stronie pracowników, jak i pracodawców. Stopniowe podnoszenie wieku emerytalnego ograniczy niedobór pracowników w stale rosnącej polskiej gospodarce i zwiększy bezpieczeństwo finansowe Polaków.

4. Dłuższa praca pozwoli zgromadzić więcej kapitału emerytalnego i ochroni przyszłych emerytów przed ubóstwem ${ }^{43}$.

Istotną kwestią jest zastępowalność pokoleń, czyli zdolność populacji do utrzymania liczby ludności na obecnym poziomie w przyszłości. Przyjmuje się, że tzw. dzietność (TFR, total fertility rate - liczba dzieci rodzonych średnio przez kobietę w całym okresie rozrodczym) na poziomie 2,1 zapewnia zastępowalność pokoleń. W Polsce TFR wynosi obecnie 1,39. Od połowy lat osiemdziesiątych obserwuje się spadek TFR. Trend ten jest zgodny z ogólnym trendem wśród 30 krajów OECD. Średnia dla OECD wynosi obecnie około $1,6^{44}$.

\footnotetext{
${ }^{41}$ M. Przepiórka, Wyższy wiek emerytalny, http://kadry.infor.pl/kadry/ubezpieczenia/emerytury_i_renty/675505,Wyzszy-wiek-emerytalny.html. 01.10 .2014

${ }^{42}$ Zwiększanie się proporcji w wieku poprodukcyjnym w stosunku do populacji w wieku przedprodukcyjnym i produkcyjnym można zilustrować również tak: jeśli obecnie na każdą osobę w wieku ponad 65 lat przypadają cztery osoby w wieku produkcyjnym, w roku 2060 na taką osobę przypadać będą tylko dwie w wieku produkcyjnym. Źródło: Zielona księga na rzecz adekwatnych, stabilnych i bezpiecznych systemów emerytalnych w Europie, Komisja Europejska, Bruksela 2010, s. 4.

${ }^{43} \mathrm{E}$. Ryś, Dlaczego podwyższany $i$ zrównywany będzie wiek emerytalny, http://www.infor.pl/prawo/emerytury/podwyzszenie-wieku-emerytalnego/303691,Dlaczegopodwyzszany-i-zrownywany-bedzie-wiek-emerytalny.html., 15.05.2013.

${ }^{44} \mathrm{M}$. Herbich, Diagnoza, analiza $i$ symulacja wariantowa możliwych ubezpieczeniowych form dobrowolnych programów emerytalnych na rynku polskim, opracowanie dla Polskiej Izby Ubezpieczeń, www.piu.org.pl/public/upload/ibrowser/Emerytalne-2n.pdf. 15.05.2013.
} 
Statystyki wskazujące na niewielki odsetek zatrudnionych w wieku poprodukcyjnym idą w parze z deklaracjami respondentów. Zatrudnieni Polacy najczęściej orzekają, że będą mogli wykonywać swoją pracę (średnio) tylko do 58,6 roku życia. Ponad 61 lat to natomiast średnia wskazywanego przez respondentów wieku zakończenia wykonywania pracy dla krajów Unii Europejskiej ${ }^{45}$. Z poniższych danych wynika również, że osobami najdłużej aktywnymi zawodowo są osoby pracujące na własny rachunek - w Polsce nieco ponad 60 lat. Najkrócej w krajach Unii Europejskiej natomiast zamierzają pracować pracownicy fizyczni (59,9 roku życia), w Polsce zaś pracownicy umysłowi niebędący kierownikami (56,4 roku życia). Należy dodać, że deklaracje Polaków nie odbiegają znacząco od rzeczywistych danych - według informacji zbieranych przez ZUS średni wiek przechodzenia na emeryturę w 2011 r. wynosił 59,5 roku, a dla mężczyzn - 60,1.

Tabela 1. Deklarowany wiek zakończenia wykonywania pracy w Polsce i Unii Europejskiej (UE)

\begin{tabular}{|c|c|c|}
\hline Rodzaj wykonywanej pracy & Polska & UE \\
\hline Ogółem & $\mathbf{5 8 , 6}$ & $\mathbf{6 1 , 7}$ \\
\hline Według wykonywanej pracy & & $\mathbf{6 4 , 9}$ \\
\hline Pracujący na własny rachunek & $\mathbf{6 0 , 7}$ & $\mathbf{6 3 , 2}$ \\
\hline Kierownicy & $\mathbf{6 0 , 0}$ & $\mathbf{6 1 , 8}$ \\
\hline Inni pracownicy umysłowi & $\mathbf{5 6 , 4}$ & $\mathbf{5 9 , 9}$ \\
\hline Źródło: & $\mathbf{5 8 , 4}$ & starzenie \\
\hline \multicolumn{2}{|c|}{ Eurobarometr, } & \\
\hline
\end{tabular}

http://analizy.mpips.gov.pl/index.php/badania-aktywne-starzenie.html. 15.05.2013

Kraje Unii Europejskiej różnią się znacząco pod względem stopnia zaawansowania procesu starzenia się obecnie i w przyszłości. Obecnie tylko w dwóch państwach co piąta osoba jest w starszym wieku (Niemcy, Włochy), natomiast w 2060 r. udział osób starszych przekroczy $20 \%$ we wszystkich krajach wspólnoty, a w zdecydowanej większości państw będzie większy niż $25 \%$. Na uwagę zasługuje fakt, że obecnie Polska

${ }^{45}$ Zob. szerzej: Z. Kaźmierczak, Rynek pracy w Unii Europejskiej w latach 1990-1994 (problemy $i$ strategia), [w:] Wspótczesne tendencje $w$ zarządzaniu zasobami pracy, Materiały $\mathrm{z}$ międzynarodowej konferencji zorganizowanej przez Katedrę Zarządzania Zasobami Pracy Akademii Ekonomicznej w Krakowie, red. A. Szałkowski, A. Piechnik-Kurdziel, Wydawnictwo Akademia Ekonomiczna, Kraków 1997, s. 17-28. 
należy do najmłodszych w sensie demograficznym ${ }^{46}$ krajów Wspólnoty (13,5\%), a Niemcy do najstarszych (20\%). Jednak w 2060 r. Polska będzie odznaczała się najwyższym udziałem osób starszych wśród obecnych 27 państw unijnych (36\%), Niemcy będą zajmowały 10 miejsce (32\%).

Wraz ze wzrostem udziału osób starszych w populacji nastąpi spadek liczby ludności w wieku produkcyjnym (potencjalne zasoby pracy, tutaj przyjęto wiek 15-64 lat), a także starzenie się tych zasobów pracy ${ }^{47}$.

Związkowcy nie chcieli się zgodzić na podniesienie i zrównanie wieku emerytalnego kobiet i mężczyzn na poziomie 67 lat. „Solidarność” jest za utrzymaniem dotychczasowych zasad: emerytura dla kobiet w wieku 60 lat, a dla mężczyzn w wieku lat 65. Związkowcy zdobyli prawie $1,4 \mathrm{mln}$ podpisów pod wnioskiem o referendum ${ }^{48}$. W akcję zbierania podpisów zaangażowało się także SLD. Według Leszka Millera Polacy mogliby w takim referendum odpowiedzieć na dwa pytania: jedno dotyczyłoby tego, czy są za podwyższeniem wieku emerytalnego do 67. roku życia, drugie zaś - czy są za propozycją przejścia na emeryturę kobiet po 35 latach pracy, a mężczyzn po 40 latach pracy, przy czym byłaby to możliwość, a nie konieczność. Miller podkreślił, że jego partia ma świadomość potrzeby zmian w systemie emerytalnym. Jednak wszelkie decyzje powinny być podejmowane $\mathrm{z}$ dużym wyprzedzeniem $\mathrm{i}$ w warunkach dialogu społecznego $^{49}$.

Głosowanie nad przyjęciem wniosku o przeprowadzenie ogólnokrajowego referendum w sprawie o szczególnym znaczeniu dla państwa i obywateli dotyczącej powszechnego wieku emerytalnego kobiet i mężczyzn przeprowadzono 30 marca 2012 r. Głosowało 455 posłów, za było 180 , przeciw - 233, wstrzymało się 42 . Większość bezwzględna wynosiła $228^{50}$.

\footnotetext{
${ }^{46}$ To znaczy pod względem udziału osób w wieku 65 lat lub więcej w populacji.

47 I.E. Kotowska, A. Abramowska-Kmon, Podnoszenie wieku emerytalnego w kontekście zmian demograficznych $w$ Polsce i Niemczech, [w:] Podnoszenie wieku emerytalnego - diagnoza potrzeb $i$ rekomendacje na przykładzie Polski i Niemiec, red. J. Kucharczyk, E. Kuźmicz, Warszawa 2011, s. 18.

${ }^{48}$ Ape, Sejm. „Nie” dla referendum $w$ sprawie podwyższenia wieku emerytalnego, http://wyborcza.pl/1,76842,11448974,Sejm__Nie_dla_referendum_w_sprawie_podwyzszenia.ht ml\#ixzz3EK5WOCRl. 22.05.2014 10.09.2014.

Zyt, Referendum w sprawie wieku emerytalnego?, http://www.rp.pl/artykul/791750.html.

${ }^{50}$ Rozpatrzenie obywatelskiego wniosku o przeprowadzenie referendum ogólnokrajowego $w$ sprawie o szczególnym znaczeniu dla państwa i obywateli dotyczacej powszechnego wieku emerytalnego kobiet i mężczyzn,

http://www.sejm.gov.pl/sejm7.nsf/agent.xsp?symbol=glosowania\&NrKadencji=7\&NrPosiedzenia= $11 \&$ NrGlosowania $=3$
} 
Tabela 2. Wyniki indywidualne

\begin{tabular}{|l|r|r|r|r|r|r|}
\hline $\begin{array}{l}\text { Klub/ } \\
\text { Koło }\end{array}$ & $\begin{array}{l}\text { Liczba } \\
\text { członków }\end{array}$ & \multicolumn{1}{l}{$\begin{array}{l}\text { Głoso- } \\
\text {-ało }\end{array}$} & Za & Przeciw & Wstrzymało się & Nie głosowało \\
\hline PO & 206 & 205 & - & $\mathbf{2 0 5}$ & - & $\mathbf{1}$ \\
\hline PiS & 136 & 134 & $\mathbf{1 3 4}$ & - & - & $\mathbf{2}$ \\
\hline RP & 42 & 42 & - & - & $\mathbf{4 2}$ & - \\
\hline PSL & 28 & 26 & - & $\mathbf{2 6}$ & - & $\mathbf{2}$ \\
\hline SLD & 26 & 26 & $\mathbf{2 6}$ & - & - & - \\
\hline SP & 20 & 20 & $\mathbf{2 0}$ & - & - & - \\
\hline Niez. & 2 & 2 & - & $\mathbf{2}$ & - & \\
\hline
\end{tabular}

\section{Źródło:}

http://www.sejm.gov.pl/sejm7.nsf/agent.xsp?symbol=glosowania\&NrKadencji=7\&NrPosi edzenia $=11 \&$ NrGlosowania=3, 10.09.2014.

Z tej analizy można zauważyć, że mimo inicjatywy referendalnych i zebrania wymaganej liczby podpisów politycy odrzucają propozycje rozpisania referendum. Z jednej strony w przedstawionych dokumentach zachęca się do podejmowania aktywności obywatelskiej, z drugiej zaś politycy sami lepiej wiedzą, co jest dla obywatela lepsze. Niechętnie podejmują dyskusje i nie dopuszczają obywateli do procesu podejmowania decyzji. Rozwiązaniem byłoby wprowadzenie przepisu o obligatoryjnym rozpisaniu referendum w wypadku zebrania odpowiednio wysokiej liczby ważnych podpisów. Obecnie nie ma znaczenia, czy obywatele zbiorą wymagane 500 tys., czy 5 milionów. Politycy w Sejmie nie muszą rozpatrywać wniosku.

Niezależnie od uwarunkowań taka sytuacja pozwala obywatelom na włączenie się do procesu podejmowania decyzji politycznych, służy pełniejszej informacji i edukacji obywatelskiej, uczy współodpowiedzialności za sprawy publiczne, wdraża do demokracji partycypacyjnej, służy legitymizacji partii politycznych czy konkretnych decyzji. Kampanie związane z przedmiotem referendum sprawiają, że nawet osoby niegłosujące są świadome przedmiotu sporu, prowadzą one bowiem do powszechnej dyskusji nad sprawami publicznymi, co w rezultacie sprzyja wzrostowi wiedzy ${ }^{51}$.

${ }^{51}$ I. Bokszczanin, Instytucja referendum ratyfikacyjnego $w$ procesie integracji $w$ Europie, [w:] Wymiar społeczny członkostwa Polski w Unii Europejskiej, red. T. Mołdawa, K.A. Wojtaszczyk, A. Szymański, Warszawa 2003, s. 369. 


\section{LITERATURA}

[1] Banaszak B., Porównawcze prawo konstytucyjne wspótczesnych państw demokratycznych, Kraków 2000.

[2] Bokszczanin I., Instytucja referendum ratyfikacyjnego $w$ procesie integracji $w$ Europie, [w:] Wymiar społeczny członkostwa Polski w Unii Europejskiej, red. T. Mołdawa, K.A. Wojtaszczyk, A. Szymański, Warszawa 2003.

[3] Czajowski J., Przedstawicielska forma rząów i demokracja bezpośrednia, [w:] Szkice o zasadach $i$ instytucjach ustrojowych II i III Rzeczypospolitej, red. J. Czajowski, M. Grzybowski, Kraków 2002.

[4] Czajowski J., Zasada podziatu władz, [w:] Szkice o zasadach $i$ instytucjach ustrojowych II i III Rzeczypospolitej, red. J. Czajowski, M. Grzybowski, Kraków 2002.

[5] Grabowska M., Polska ustawa o referendum ogólnokrajowym (referenda akcesyjne), „Studia Europejskie” 2003/1.

[6] Grabowska S., Formy demokracji bezpośredniej w wybranych państwach europejskich, Rzeszów 2009.

[7] Grabowska S., Instytucja ogólnokrajowej inicjatywy ludowej w wybranych państwach europejskich, Rzeszów 2005.

[8] Grabowska S., Równość szans $w$ dostępie do form demokracji bezpośredniej $w$ wybranych państwach europejskich, [w:] Zasada równości w prawie, red. H. Zięba-Załucka, M. Kijowski, Rzeszów 2004.

[9] Jabłoński M., Wynik referendum, a zasada dyskontynuacji prac parlamentu, „Przegląd Prawa i Administracji” 1998/XLI.

[10]Jastrzębski B., O demokracji bezpośredniej, „Zeszyty Naukowe Wyższej Szkoły Pedagogicznej w Olsztynie” nr 10, „Nauki Prawne” 1989/1.

[11]Kaźmierczak Z., Rynek pracy w Unii Europejskiej w latach 1990-1994 (problemy $i$ strategia), [w:] Wspótczesne tendencje $w$ zarządzaniu zasobami pracy, Materiały z międzynarodowej konferencji zorganizowanej przez Katedrę Zarządzania Zasobami Pracy Akademii Ekonomicznej w Krakowie, red. A. Szałkowski, A. Piechnik-Kurdziel, Wydawnictwo Akademia Ekonomiczna, Kraków 1997.

[12]Kotowska I.E., Abramowska-Kmon A., Podnoszenie wieku emerytalnego w kontekście zmian demograficznych $w$ Polsce $i$ Niemczech, [w:] Podnoszenie wieku emerytalnego - diagnoza potrzeb i rekomendacje na przyktadzie Polski $i$ Niemiec, red. J. Kucharczyk, E. Kuźmicz, Warszawa 2011.

[13]Kuciński J., Demokracja przedstawicielska $i$ bezpośrednia $w$ trzeciej Rzeczypospolitej, Warszawa 2007.

[14]Litawski J., Bezpośrednie ustawodawstwo ludowe, Kraków 1932.

[15]Marczewska-Rytko M., Szwajcarski model demokracji bezpośredniej, [w:] Stan i perspektywy demokracji bezpośredniej we współczesnym świecie, Lublin 2011.

[16] Mrozowska S., Demokracja uczestniczaca perspektywy europejskiej, [w:] Stan i perspektywy demokracji bezpośredniej we wspótczesnym świecie, red. M. Marczewsk-Rytko, Lublin 2011.

[17]Musiał-Karg M., Referenda w państwach europejskich - teoria , praktyka, perspektywy, Torun 2008. 
[18]Pietrzak M., Demokracja reprezentacyjna $i$ bezpośrednia w Konstytucji Rzeczypospolitej Polskiej, [w:] Referendum konstytucyjne w Polsce, red. M.T. Staszewski, Warszawa 1997.

[19]Podolak M., Rola i znaczenie demokracji bezpośredniej we współczesnych państwach, [w:] Polityczne wyzwania współczesnych państw. Perspektywa globalna, t. 1, red. W. Gizicki, Lublin 2011.

[20]Podolak M., Demokratyzacja społeczeństwa polskiego $w$ okresie transformacji, [w:] Aksjologiczny i pragmatyczny wymiar wspótczesnej polityki, red. D. Walczak-Duraj, Łódź 2011.

[21]Popławska E., Zasada rząów przedstawicielskich i formy demokracji bezpośredniej, [w:] Zasady podstawowe polskiej Konstytucji, red. W. Sokolewicz, Warszawa 1998.

[22]Rachwał M., Demokracja bezpośrednia w procesie ksztattowania się społeczeństwa obywatelskiego, Warszawa 2010.

[23] Skrzydło W., Konstytucja Rzeczypospolitej Polskie. Komentarz, Kraków 2002.

[24] Sokolewicz W., Tezy do art. 225, [w:] Konstytucja Rzeczypospolitej Polskiej. Komentarz, red. L. Garlicki, t. II, Warszawa 2001.

[25]Szmyt A., Zasady zmiany konstytucji Rzeczypospolitej Polskiej, [w:] Zasady zmiany konstytucji w państwach europejskich, red. R. Grabowski, S. Grabowska, Warszawa 2008.

[26] Ustawa z 24 czerwca 1999 r. o wykonywaniu inicjatywy ustawodawczej przez obywateli, Dz.U. 1999 nr 62, poz. 688.

[27]Uziębło P., Inicjatywa ustawodawcza obywateli $w$ Polsce na tle rozwiazań ustrojowych państw obcych, Warszawa 2006.

[28]Zielona księga na rzecz adekwatnych, stabilnych $i$ bezpiecznych systemów emerytalnych w Europie, Komisja Europejska, Bruksela 2010.

\section{Źródła internetowe}

[1] Ape, Sejm. „Nie” dla referendum w sprawie podwyższenia wieku emerytalnego, http://wyborcza.pl/1,76842,11448974,Sejm__Nie_dla_referendum_w_sprawie _podwyzszenia.html\#ixzz3EK5WOCRl. 22.05.2014.

[2] Degreit A., Weto ludowe, http://alexdegrejt.salon24.pl/405985, weto-ludowe. Program Partii Demokracja Bezpośrednia http:/ db.org.pl/sites/default/files/turkusowa_rewolucja.pdf. 15.06.2014.

[3] Dokument Programowy $\quad X \quad$ zjazdu http://www.psl.org.pl/upload/pdf/dokumenty/Dokumenty_X_Kongres_PSL/Dok umenty_Programowe_X_Kongresu_PSL_.pdf., 20.08.2014.

[4] Herbach M., Diagnoza, analiza $i$ symulacja wariantowa możliwych ubezpieczeniowych form dobrowolnych programów emerytalnych na rynku polskim, opracowanie dla Polskiej Izby Ubezpieczeń, www.piu.org.pl/public/upload/ibrowser/Emerytalne-2n.pdf. 15.05.2013.

[5] http://www.tvn24.pl/wiadomosci-z-kraju,3/przegrali-bitwe-o-referendum-ws-6latkow-walcza-o-odmrozenie-projektu-rodzice-beda-pamietac, 373758.html. 22.09.2014 
[6] Następny krok. Razem. Program wyborczy 2011, http://www.platforma.org/media/dokumenty/Program_PO_100dpi.pdf. 05.09.2014

[7] Konstytucja Rzeczypospolitej Polskie, projekt Prawa i Sprawiedliwości, Warszawa 2010, file:///C:/Users/admin/Downloads/konstytucja_2010.pdf, 21.09.2014.

[8] Nie będzie referendum ws. 6-latków. Koalicja wygrała głosowanie, http://www.tvn24.pl/wiadomosci-z-kraju,3/nie-bedzie-referendum-ws-6-latkowkoalicja-wygrala-glosowanie,369867.html.22.09.2014.

[9] PAP, Elbanowski: spotkanie z premierem ws. sześciolatków było bez konkretów, http://wiadomosci.wp.pl/kat,59154,title,Elbanowski-spotkanie-z-premierem-wsszesciolatkow-bylo-bezkonkretow,wid,16131265,wiadomosc.html?ticaid=113823. 20.07.2014

[10]PiS złożyt wniosek o referendum ws. 6-latków, http://wiadomosci.wp.pl/kat,1342,title,PiS-zlozyl-wniosek-o-referendum-ws-6latkow,wid,16181393, wiadomosc.html?ticaid=113824.20.07.2014.

[11]Program PiS 2014 Projekt dla Polski, file:///C:/Users/admin/Downloads/program_pis_2014.pdf, 15.09.2014,

[12]Program Twojego Ruchu Plan Zmian 2014-2019, http://twojruch.eu/wpcontent/uploads/2014/09/plan-zmian.pdf, 15.09.2014.

[13]Program wyborczy Sojuszu Lewicy Demokratycznej, Jutro bez obaw Program dla Polski, 2011. http://www.sld.org.pl/strony/39jutro_bez_obaw__program_sld.html, 10.09.2014

[14]Przedstawienie przez prezesa Rady Ministrów Donalda Tuska programu działania Rady Ministrów z wnioskiem o udzielenie jej wotum zaufania 23.11.2007 r., ,Sprawozdanie Stenograficzne z 2 posiedzenia Sejmu RP w dniu 23 listopada 2007 r." http://orka2.sejm.gov.pl/StenoInter6.nsf/0/6372FE4B9619C127C125739D0053E 245/\$file/2_a_ksiazka.pdf. 20.09.2014.

[15]Przedstawienie przez prezesa Rady Ministrów Donalda Tuska programu działania Rady Ministrów z wnioskiem o udzielenie jej wotum zaufania 18.11.2011. „Sprawozdanie Stenograficzne z 1 posiedzenia Sejmu RP w dniu 18 listopada 2011

r.", http://orka2.sejm.gov.pl/StenoInter7.nsf/0/B635A8E7E273395DC125794D000D A7A6/\%24File/1_c_ksiazka.pdf. 20.09.2014

[16]Przedstawienie przez Prezesa Rady Ministrów programu działania Rady Ministrów z wnioskiem o udzielenie jej wotum zaufania, „Sprawozdanie Stenograficzne z 76 posiedzenia Sejmu RP w dniu 1 października 2014 r.”, http://orka2.sejm.gov.pl/StenoInter7.nsf/0/D4E8C869CD930B1DC1257D64007 A0F97/\%24File/76_ksiazka.pdf. 20.09.2014

[17]Przepiórka Myżsy wiek emerytalny, http://kadry.infor.pl/kadry/ubezpieczenia/emerytury_i_renty/675505,Wyzszywiek-emerytalny.html.01.10.2014.

[18]Ratujmy maluchy u premiera 27 grudnia, http://www.rzecznikrodzicow.pl/ratujmaluchy-u-premiera-27-grudnia. 20.07.2014

[19]Ratuj maluchy u Millera 24.09, http://www.rzecznikrodzicow.pl/ratuj-maluchyu-millera-2409.20.07.2014 
[20]Referendum edukacyjne „Ratujmy maluchy $i$ starsze dzieci te $\dot{~}$, http://www.rzecznikrodzicow.pl/referendum-edukacyjne-ratuj-maluchy-i-starszedzieci-tez. 20.07.2014.

[21]Rozpatrzenie obywatelskiego wniosku o przeprowadzenie referendum ogólnokrajowego $w$ sprawie o szczególnym znaczeniu dla państwa i obywateli dotyczacej powszechnego wieku emerytalnego kobiet $i$ mężczyzn, http://www.sejm.gov.pl/sejm7.nsf/agent.xsp?symbol=glosowania\&NrKadencji= $7 \&$ NrPosiedzenia $=11 \&$ NrGlosowania $=3.10 .09 .2014$

[22]Ryś E., Dlaczego podwyższany i zrównywany będzie wiek emerytalny, http://www.infor.pl/prawo/emerytury/podwyzszenie-wiekuemerytalnego/303691,Dlaczego-podwyzszany-i-zrownywany-bedzie-wiekemerytalny.html. 15.05.2013.

[23] Ustawa z 11 maja 2012 r. o zmianie ustawy o emeryturach i rentach z Funduszu Ubezpieczeń Społecznych oraz niektórych innych ustaw, Dz.U. 2012, poz. 637.

[24] Wypowiedzi na posiedzeniach Sejmu, Posiedzenie nr 53 w dniu 08-11-2013 (3. dzień obrad); http://www.sejm.gov.pl/Sejm7.nsf/wypowiedz.xsp?posiedzenie=53\&dzien=3\&w $\mathrm{yp}=33 \&$ view $=1.05 .09 .2014$.

[25]Zyt, Referendum w sprawie wieku emerytalnego?, http://www.rp.pl/artykul/791750.html.22.05.2014

\section{DIRECT DEMOCRACY IN POLITICAL THOUGHT OF MODERN POLITICAL PARTIES IN POLAND}

The main objective of the article is to present political parties in Poland and their documents related to direct democracy. Direct democracy gives the right to decide on particular issues to every citizen. In Poland we have instruments of direct democracy: referendums and popular initiatives. Referendums are a right given to citizen by the constitution. People can initiate a referendum by collecting 500 thousands signatures.

On the one hand we can find a lot of information in parties documents about building a civil society in our country. Politicians invite people to take part in the process of decision making. But on the other hand, politicians do not agree to promulgate a referendum. They show no regard for populations' wishes and demands but rather autocratically impose their own preferences. In the article Author gave two examples: government's decision on the extend of 6-year-old compulsory school and equalization of retirement age for men and women. In both cases people initiated referendum and collected the required number of signatures. Politicians does not agree to vote. Decision-makers in all political areas find it difficult or even impossible to imagine that citizens are motivated and capable of participating in politics. This is a general feature of such decision-makers - once they are in power. The reason is simple: politicians do not want to share power with the population.

Keywords: direct democracy, political partie, referendum.

DOI:10.7862/rz.2015.hss.12

Przesłano do redakcji: listopad 2014

Przyjęto do druku: czerwiec 2015 